\title{
ANALISIS POSTINGAN DI TWITTER MENGENAI VAKSINASI COVID-19: PERILAKU SOSIAL TERHADAP VAKSINASI COVID- 19 GUNA PENCEGAHAN PENULARAN COVID-19
}

\author{
Khoirun Nisa Aulia Sukmani \\ Anthropological researcher, Indonesia \\ e-mail: auliasukmani@gmail.com
}

\begin{tabular}{l}
\hline \multicolumn{1}{c}{ Article Inf } \\
\hline Keyword: \\
Covid-19 \\
Social behavior \\
Community \\
Intersubjectivity \\
Telecopresence \\
Self-evidence
\end{tabular}

\begin{abstract}
The Covid-19 pandemic is a new event experienced by all Indonesians and also the world. This pandemic emerges with new patterns and problems that affect human social behavior as individuals and society. Information is an important thing that must be known by humans to deal with changing patterns and problems that occur. In this pandemic era, humans are actively interacting on social media, as a form of escape from the policy of prohibiting physical interaction to reduce virus transmission. Interactions that occur between humans are a form of sharing experiences and knowledge that are owned for the benefit of humans themselves. How is this explained? interaction as social behavior must be interpreted more deeply as a human process to seek knowledge and experience that has a purpose and purpose in it. This goal is actually to ensure that humans themselves have the knowledge to deal with the changes that have occurred due to the emergence of the Covid-19 pandemic. The social media ethnography method is used to see the process of interaction on social media continuously until finally, humans can prove that they have the ability and knowledge to understand and behave in the era of the Covid-19 pandemic. The social media Twitter is used to see the interactions that occur between Indonesian netizens regarding the Covid-19 incident, especially the Covid-19 vaccination which was carried out in Indonesia. Repetitive interactions that are carried out form self-evidences, which are used to confirm and better observe events with prior knowledge. This knowledge is a form of reference used by humans to act when facing certain events, in this case responsding to every event during the Covid-19 pandemic.
\end{abstract}

\begin{tabular}{ll}
\hline \multicolumn{1}{c}{ Article Info } & Abstrak \\
& Pandemi Covid-19 merupakan peristiwa baru yang dialami oleh \\
Kata Kunci: & seluruh masyarakat Indonesia dan juga dunia. Pandemi ini muncul \\
Covid-19 & dengan pola dan masalah baru yang memengaruhi perilaku sosial \\
Perilaku sosial & manusia sebagai individu dan masyarakat. Informasi merupakan hal \\
Komunitas & penting yang harus diketahui oleh manusia untuk menghadapi \\
Intersubjectivity & perubahan pola dan masalah yang terjadi. Di era pandemi ini, manusia \\
Telecopresence & aktif berinteraksi di media sosial sebagai bentuk pelarian dari \\
Self-evidence & kebijakan pelarangan interaksi fisik untuk mengurangi penularan \\
& virus. Interaksi yang terjadi antarmanusia merupakan bentuk saling \\
& berbagi pengalaman dan pengetahuan yang dimiliki untuk \\
& kepentingan manusia itu sendiri. Bagaimana ini dijelaskan? interaksi \\
& sebagai perilaku sosial harus dimaknai lebih dalam sebagai proses \\
& manusia untuk mencari pengetahuan dan pengalaman yang memiliki \\
& maksud dan tujuan di dalamnya. Tujuan ini sebenarnya untuk \\
\hline
\end{tabular}


memastikan bahwa manusia itu sendiri memiliki pengetahuan untuk menghadapi perubahan yang terjadi akibat munculnya pandemi Covid-19. Metode social media ethnography digunakan untuk melihat proses interaksi di media sosial secara terus menerus hingga akhirnya manusia dapat membuktikan bahwa dirinya memiliki kemampuan dan pengetahuan untuk memahami dan berperilaku di era pandemi Covid19. Media sosial Twitter digunakan untuk melihat interaksi yang terjadi antarnetizen Indonesia terkait kejadian Covid-19, khususnya vaksinasi Covid-19 yang dilakukan di Indonesia. Interaksi berulang yang dilakukan membentuk bukti diri yang digunakan untuk mengonfirmasi dan mengamati peristiwa dengan lebih baik dengan pengetahuan sebelumnya. Pengetahuan ini merupakan bentuk acuan yang digunakan manusia untuk bertindak ketika menghadapi peristiwa tertentu, dalam hal ini menanggapi setiap peristiwa selama pandemi Covid-19.

\section{Pendahuluan}

Pandemi Covid-19 telah bertahan selama lebih dari satu tahun, penularan virus ini menjadi masalah utama untuk diselesaikan di berbagai negara. Covid-19 mulai menjadi perhatian Pemerintah dan masyarakat di Indonesia pada bulan Maret 2020, setelah 2 warga Depok resmi terdampak Covid19 (Ihsanuddin, 2020). Pemerintah mulai melakukan penanggulangan sesuai arahan WHO (World Health Organization) yaitu physical disctancing (Webmaster, 2020). Indonesia sendiri kemudian menerapkan aturan pencegahan Covid-19 yang menimbulkan reaksi berbeda di masyarakat yaitu PSBB (Pembatasan Sosial Berskala Besar) (Wibowo, 2020). Selanjutnya, Pemerintah menerapkan kebijakan New normal (Administrator, 2020) yang juga menimbulkan respons berbeda di masyarakat karena kebijakan ini dinilai dapat meningkatkan penyebaran virus Covid-19. Namun, pemerintah menerapkan protokol kesehatan ketat (Silalahi, 2020) guna mewujudkan cara hidup baru masyarakat di tengah pandemi Covid-19.

PSBB yang diterapkan di Indonesia memiliki peraturan dan pelaksanaan yang berbeda menurut Peraturan Daerah masing-masing (Mashabi, 2020). PSBB mendapat respons yang berbeda, sebagian masyarakat tidak memedulikan kebijakan ini karena tidak percaya adanya virus Covid-19 dan masalah sosial ekonomi, sedangkan sebagian lagi menaati peraturan tersebut. Masyarakat yang kurang menaati peraturan ini karena permasalahan perekonomian (Jaya, 2020). Kebijakan ini menyebabkan banyak karyawan mengalami pemutusan hubungan kerja (PHK), pedagang merugi, dan karena tidak dianjurkan keluar rumah, bagi sebagian masyarakat yang menggantungkan hidup dari upah harian menjadi tidak ada pemasukan untuk mencukupi kehidupan. Akibatnya, muncul permasalahan baru yang juga perlu diatasi oleh pemerintah yaitu aksi kriminal dilakukan oleh masyarakat karena terhimpit masalah ekonomi (Manurung, 2020).

Polarisasi perilaku sosial masyarakat saat PSBB berubah isu ketika pemerintah menerapkan kebijakan baru, yaitu new normal. Kebijakan baru ini memunculkan polarisasi perilaku sosial yang sama, masyarakat terbagi menjadi masyarakat yang setuju dengan adanya penerapan new normal karena aktivitas ekonomi, perdagangan, dan karyawan banyak yang sudah diperbolehkan bekerja dengan penerapan protokol kesehatan (Advetorial, 2020). Sebaliknya, masyarakat yang kurang setuju karena kebijakan ini karena berpotensi menaikkan penyebaran virus Covid-19, menurut Nuning Nuraini, Kepala Pusat Pemodelan Matematika dan Simulasi ITB menjelaskan bahwa "Dari data saja, ini masih menanjak dan belum ada puncak. Apalagi gelombang kedua. ..." "Bahkan ini yang 9 Juli kisaran 1.2-1.4, artinya masih mungkin menyebar. Apalagi nanti kalau ditambah mobilitas meningkat" (Tambunan, 2020).

Polarisasi perilaku ini kemudian berlangsung sampai informasi bahwa vaksin Covid-19 telah ditemukan dan akan di buat secara massal untuk pencegahan virus Covid-19 (Franedya, 2020). 
Indonesia menjadi salah satu negara yang mengantri untuk mendapat vaksin ini guna diberikan secara gratis kepada masyarakat. Vaksin merupakan zat atau senyawa yang digunakan guna membentuk kekebalan tubuh terhadap suatu penyakit, dibuat dari virus penyakit tersebut yang telah dilemahkan (Kementerian Kesehatann RI, 2014). Peristiwa vaksinasi Covid-19 ini tentunya juga dapat menimbulkan polarisasi perilaku sosial akibat respons yang berbeda-beda di masyarakat, jadi pertanyaannya adalah apakah respons masyarakat akan menunjukkan polarisasi yang sama seperti sebelumnya? Menurut Erick Thohir Menteri BUMN dan Ketua Komite Penanganan Covid-19 mengatakan bahwa terdapat $16 \%$ masyarakat Indonesia yang tidak mau divaksin dan $66 \%$ sisanya mau untuk divaksin (Rosana, 2020). Sebagai contoh kontroversi vaksin Covid-19 di Indonesia, yaitu bagi umat muslim, meragukan kehalalan vaksin ini karena isu bahwa vaksin ini mengandung Babi (Babi menurut ajaran Islam haram hukumnya) (Wirawan, 2020), sedangkan umat Kristiani meragukan kandungan vaksin ini karena beredar isu kandungan gen antiKristus dan microchip 666 (Nicolas, 2021).

Perilaku masyarakat selama pandemi Covid-19 tidak hanya dibatasi dalam ruang yang nyata, tetapi juga aktif menunjukkan perilaku nyata di ruang maya. Jelasnya, perilaku nyata di ruang maya tersebut sama dengan perilaku sosial di dunia nyata. Perilaku sosial sendiri merupakan respons manusia secara spontan ketika sedang berinteraksi di masyarakat.

"Paradigma perilaku sosial melihat perilaku manusia dalam interaksi sosial sebagai respons atau tanggapan (reaksi mekanis yang bersifat otomatis) dari sejumlah stimulus atau rangsangan yang muncul dalam interaksi tersebut. Reaksi mekanis dan otomatis seperti itu kerap terjadi dalam interaksi antarindividu (Veeger, 1993: 26).” (Wirawan, 2012).

Wirawan (2012) menjelaskan lebih lanjut bahwa paradigma ini hanya melihat respons tersebut secara empiris, apa yang menyebabkan dan maksud dari perilaku tersebut tidak diamati (Wirawan, 2012). Artinya, paradigma ini hanya melihat mengapa perilaku tersebut ada tanpa memahami penyebabnya dan mengapa perilaku tersebut dilakukan, tidak melihat bagaimana proses di baliknya.

Perilaku manusia tentunya tidak secara otomatis terbentuk, maksudnya perilaku terbentuk berdasarkan pengalaman yang dialami. Interaksi yang dialami oleh manusia merupakan pengalaman yang digunakan sebagai pembelajaran untuk mengamati perilaku dan pengetahuan dari orang lain. Dapat dikatakan bahwa manusia belajar dari pengamatan terhadap perilaku dan pengetahuan dari orang lain, kemudian diproses dengan pengetahuan yang dimiliki untuk menghasilkan pengetahuan dan perilaku baru yang berguna untuk berinteraksi. Interaksi dalam penelitian ini merujuk pada interaksi yang dilakukan manusia di dunia maya, yaitu media sosial Twitter, di mana manusia memiliki akun untuk berinteraksi satu dengan lain melalui replay dan retweet di Twitter selama pandemi Covid-19 (penelitian ini merujuk pada pembahasan vaksinasi Covid-19). Penalaran mengenai pembelajaran dan pengematan interaksi manusia merujuk pada konsep intersubjectivity dari Alfred Schutz dan konsep telecopresence Shanyang Zhao yang saling berhubungan untuk melihat hasil dari interaksi yang dilakukan oleh manusia di dunia maya (media sosial) (Sukmani, 2018).

\section{Metode Penelitian}

Penelitian ini berawal dari keresahan penulis mengenai polarisasi perilaku sosial yang muncul pada masyarakat Indonesia selama pandemi Covid-19, interaksi dan diskusi mengenai peristiwa Covid-19 menimbulkan banyak pengetahuan baru untuk merespons apa yang akan terjadi selanjutnya. Peristiwa baru, yaitu vaksinasi Covid-19 menjadi isu menarik untuk dilihat apakah polarisasi perilaku sosial tersebut muncul kembali di masyarakat. Lebih fokusnya, pernyataan penelitian ini adalah "Perilaku sosial dan intersubjectivity dalam interaksi yang terjadi di media sosial Twitter menjadi bagian dari proses pengamatan perilaku, pengetahuan, dan pengalaman baru manusia adalah untuk menemukan self-evidence dalam merespons peristiwa yang terjadi di kemudian hari (dalam penelitian ini selama pandemi Covid-19)". Data penelitian ini diambil menggunakan metode 
social media ethnography, tempat penelitian adalah media sosial Twitter, dan data yang diambil berfokus pada perilaku sosial dari postingan akun Twitter masyarakat Indonesia mengenai vaksin Covid-19, serta melakukan studi pustaka sebagai upaya untuk mendukung penjelasan data yang diamati. Artikel ini akan terdiri dari tiga bagian, yaitu 1) membahas mengenai perilaku sosial masyarakat Indonesia di akun media sosial Twitter mengenai informasi vaksinasi Covid-19; 2) membahas respons di media sosial Twitter tersebut kemudian berkembang menjadi isu penting untuk didiskusikan guna mendapatkan pengetahuan baru; dan 3) menemukan self-evidence mengenai vaksinasi Covid-19 yang disebabkan dari perilaku sosial yang berulang selama masa pandemi Covid19 di Indonesia.

\section{Pembahasan}

Perilaku Sosial di Media Sosial Twitter terhadap Vaksinasi Covid-19 di Indonesia

Selama masa pandemi Covid-19, banyak sekali perilaku sosial baru yang terjadi sebagai bentuk respons dari masyarakat terhadap peristiwa yang belum pernah dihadapi sebelumnya. Perilaku sosial ini tidak hanya terjadi secara nyata di dunia nyata, namun juga secara nyata di dunia maya. Media sosial merupakan ruang interaksi yang digunakan oleh masyarakat Indonesia selama pandemi untuk berinteraksi, merespons isu atau peristiwa yang sedang terjadi. Twitter merupakan sosial media yang menyediakan ruang kepada penggunanya untuk mengunggah apapun yang diinginkan (penelitian ini merujuk pada postingan mengenai vaksinasi Covid-19), Twitter juga menyediakan bentuk respons untuk mendukung unggahan penggunanya yaitu replay, love, retweet, dan quote retweet baru-baru ini Twitter menambah fitur fleets (seperti story di instagram) (Twitter, n.d.).

Membahas mengenai perilaku sosial yang dilakukan oleh netizen (sebutan bagi manusia yang berinteraksi di media sosial (komunitas) yang melakukan interaksi di dunia maya) di dunia maya, interaksi sosial yang terjadi berbentuk postingan dan respons-membalas postingan akun lain. Perilaku sosial menurut pandangan Prof. Wirawan (2012) menyatakan bahwa:

\section{"Berbeda dengan definisi sosial ... dalam paradigma perilaku sosial ini sangat menekankan pada pendektaan yang bersifat objektif empiris. Meskipun sama- sama berangkat dari pusat perhatian yang sama yakni "interaksi antarmanusia" tetapi paradigma perilaku sosial menggunakan sudut pandang "perilaku sosial yang teramati dan dapat dipelajari”. Jadi, dalam paradigmaa ini perlaku sosial itulah yang menjadi persoalan ... . Sementara apa yang dibalik perilaku itu (misalnya saja: maksud dari perilaku tertentu, motivasi di balik perilaku itu...) berada di luar sudut pandang paradigma perilaku sosial ini.”(Wirawan, 2012).}

Perilaku sosial merupakan responss spontan manusia ketika berinteraksi di masyarakat tanpa memperhatikan penyebab atau maksud di belakangnya. Anggap saja bahwa postingan dan respons atas postingan yang ada di Twitter adalah bentuk perilaku sosial secara spontan yang dilakukan oleh netizen tanpa pembaca postingan tersebut harus tahu maksud dan penyebab di belakangnya. Berikut postingan Twitter akun masyarakat Indonesia sebagai bentuk perilaku sosial mengenai vaksinasi Covid-19, periode postingan yang diambil untuk penelitian ini adalah mulai November 2020 sampai dengan Februari 2021. Periode ini diambil karena mulai bulan November vaksin Covid-19 sudah mulai tahap uji coba klinis dan kemudian siap untuk di gunakan untuk masyarakat. Periode ini juga terdapat peristiwa politik yang terjadi di Indonesia dan dikaitkan dengan penyebaran pandemi Covid19, periode awal tahun Januari-Februari 2021 vaksin mulai disebarkan ke masyarakat dan dengan kondisi masyarakat mulai mendapatkan kebenaran informasi tentang vaksin Covid-19. Berdasarkan hasil penelitian tedapat tujuh bentuk postingan dalam merespons vaksinasi Covid-19 di Indonesia sebagai berikut. 
1. Postingan sebagai respons terhadap kebijakan pemerintah

Respons pertama mengenai postingan netizen sebagai respons terhadap postingan pemerintah. Pemerintah telah melakukan berbagai upaya untuk menanggulangi penularan virus Covid-19. Berikut adalah respons netizen atas upaya-upaya tersebut.

Gambar 1. Capture postingan netizen mengenai respons terhadap upaya pemerintah dalam pencegahan virus Covid-19

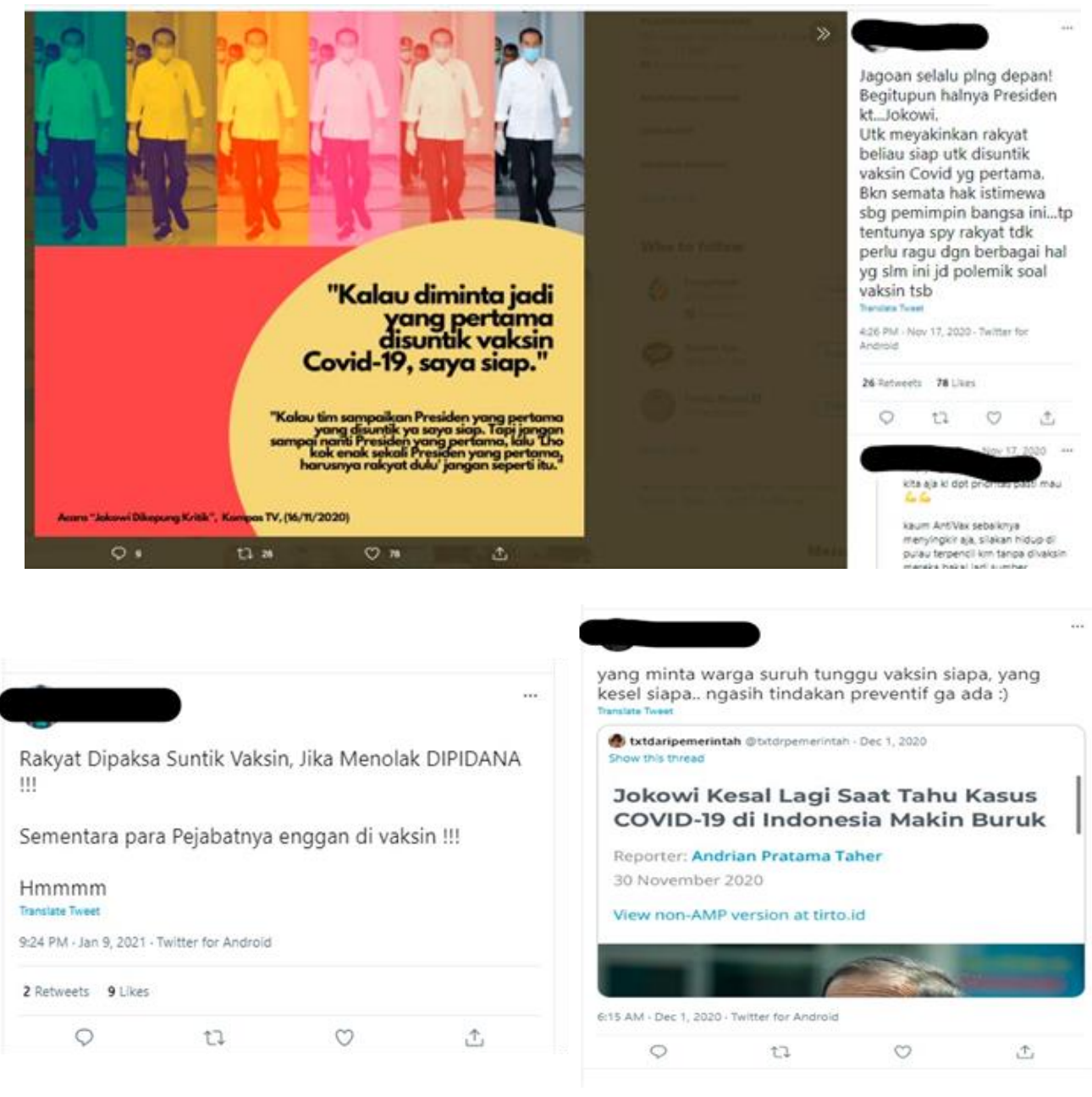

Sumber: Data Pribadi

Respons yang saya tampilkan pada gambar 1 menunjukkan bahwa terjadi polarisasi dalam masyarakat, yaitu terdapat perilaku berbeda dalam menghadapi peristiwa selama masa pandemi Covid-19 di Indonesia.

2. Postingan sebagai respons terhadap permasalahan ekonomi

Respons kedua mengenai permasalan utama yang dialami selama pandemi Covid-19, yaitu ekonomi. Masalah ekonomi menjadi pembahasan krusial para ahli sosial dan Pemerintah, karena pandemi Covid-19 ini benar-benar menjadikan perekonomian di Indonesia menurun drastis. Banyak masyarakat yang kehilangan pekerjaan dan tidak dapat memenuhi kebutuhan sehari-hari kerena tidak memiliki penghasilan (terutama masyarakat yang mengandalkan upah harian untuk mencukupi kebutuhan sehari-hari). Berikut adalah respons netizen. 
Gambar 2. Capture respons netizen terhadap bidang ekonomi jika dilakukan vaksinasi Covid-19
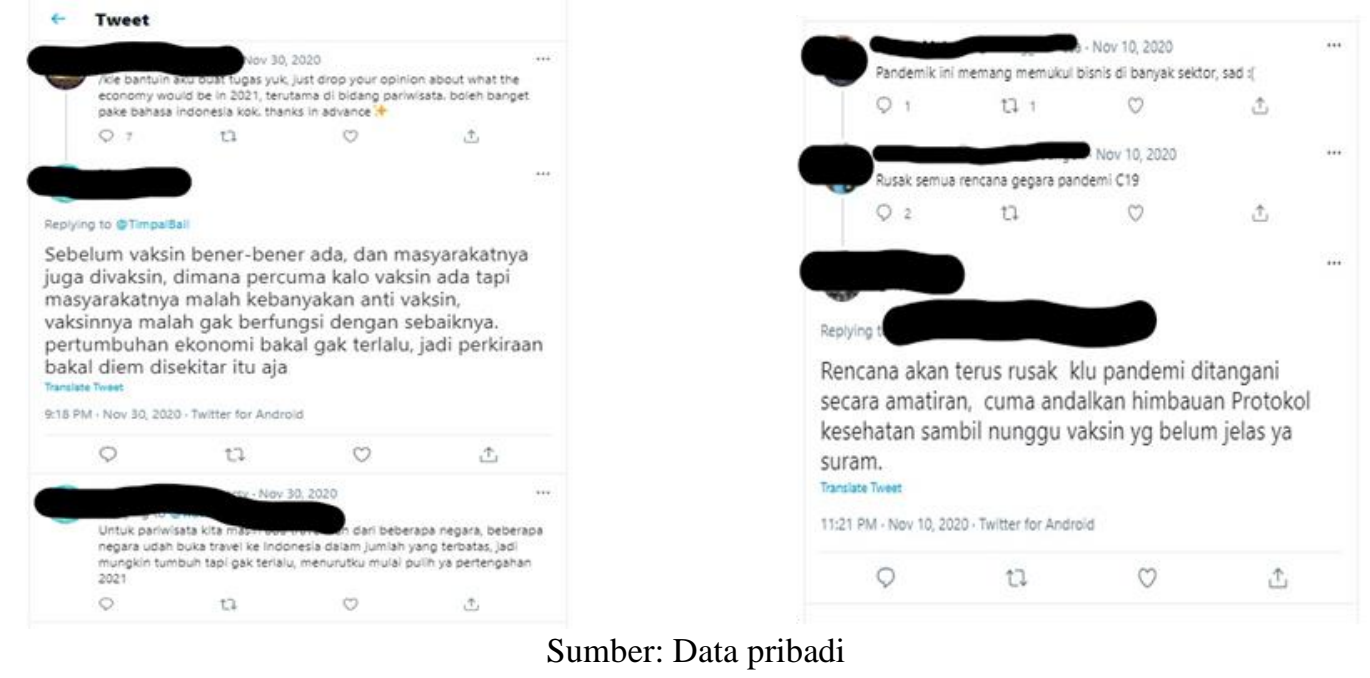

Gambar 2 memperlihatkan bahwa dengan dilaksanakannya vaksinasi Covid-19 dapat mengurangi kekhawatiran masyarakat untuk tertular Covid-19 dan dengan perlahan masyarakat dapat memulihkan aktivitas ekonomi mereka.

3. Postingan sebagai respons terhadap informasi dan pendapat para ahli

Respons ini adalah postingan netizen mengenai informasi yang beredar mengenai vaksin Covid-19 dan pendapat para ahli yang direspons oleh netizen. Berikut postingan tersebut.

Gambar 3. Capture postingan netizen mengenai informasi vaksin dan pendapat para ahli

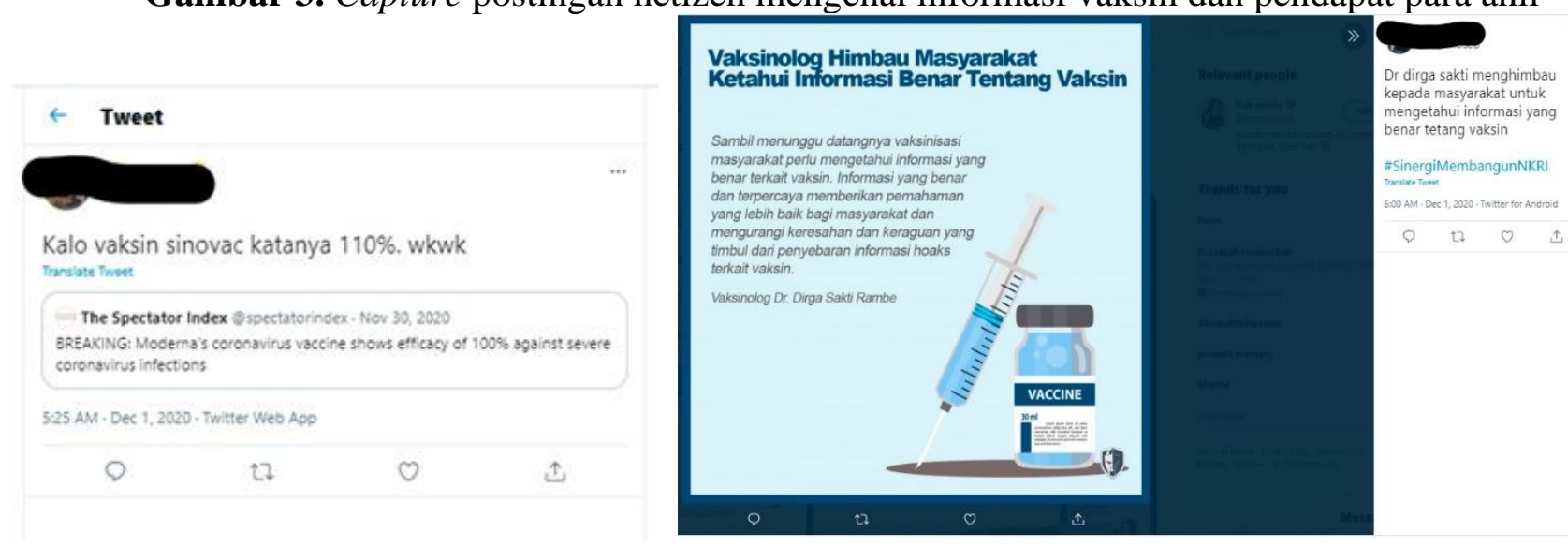

Sumber: Data pribadi

Gambar 3 menjelaskan bahwa netizen aktif mencari informasi (kebenaran) mengenai vaksin Covid-19. Bagaimana vaksin ini bekerja dan bagaimana vaksin ini dibuat, dari pengetahuan tersebut barulah netizen dapat menyimpulkan apakah vaksinasi Covid-19 tersebut perlu atau tidak dilakukan.

4. Postingan sebagai respons terhadap dukungan vaksinasi Covid-19

Selanjutnya adalah respons netizen yang memberikan dukungan terhadap pelaksanaan vaksinasi Covid-19. Saya sudah sedikit menyinggung bahwa perilaku sosial masyarakat mengenai vaksin Covid-19 memiliki respons yang berbeda salah satunya adalah masyarakat yang mendukung pelaksanaan vaksinasi Covid-19, dukungan ini diberikan karena masyarakat ingin pandemi ini cepat selesai. Berikut postingan netizen. 
Gambar 4. Capture postingan netizen yang memberikan dukungan terhadap vaksinasi Covid19
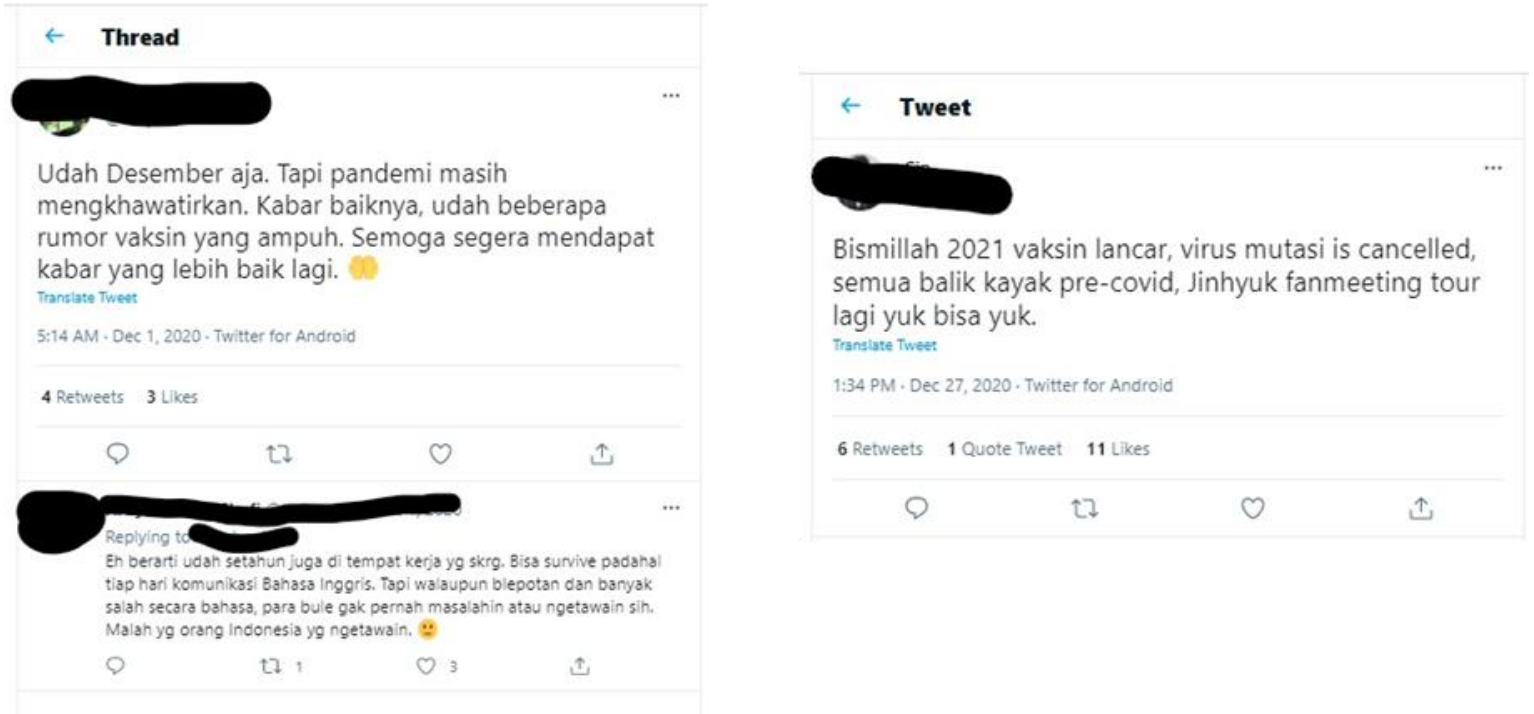

Sumber: Data pribadi

Postingan di atas menunjukkan bahwa respons dukungan yang diberikan oleh netizen memiliki maksud dan tujuan tertentu di belakangnya.

5. Postingan sebagai respons terhadap penolakan vaksinasi Covid-19

Jika ada yang mendukung, perilaku sosial masyarakat pasti ada yang menolak. Penolakan oleh masyarakat juga tersampaikan dalam postingan netizen di Twitter berikut.

Gambar 5. Capture postingan netizen mengenai penolakan vaksinasi Covid-19
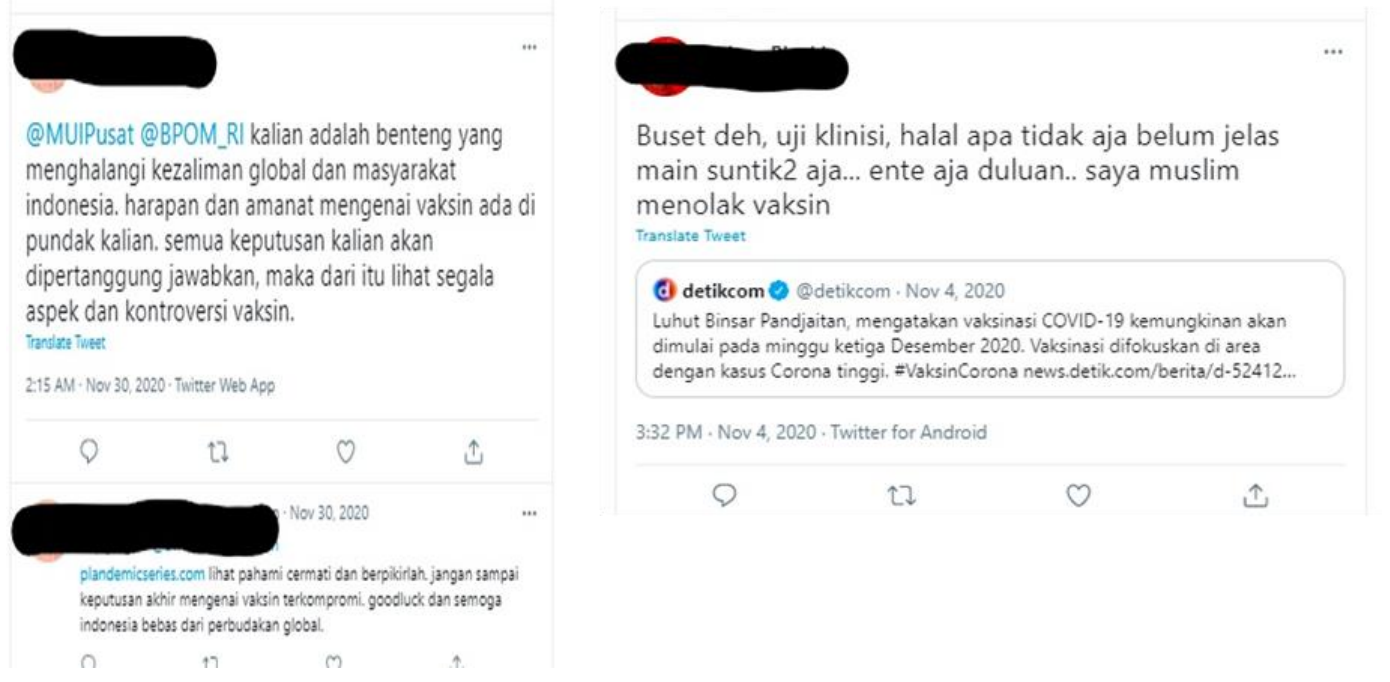

Sumber: Data pribadi

Respons negatif dari masyarakat ini sebenarnya sebagai bentuk proteksi masyarakat terhadap hal buruk yang akan terjadi jika melakukan aktivitas atau perilaku tanpa memiliki pengetahuan yang cukup. Jadi sebenarnya bentuk penolakan ini adalah wajar terjadi dalam perilaku sosial manusia saat berinteraksi di masyarakat. 
6. Postingan sebagai respons terhadap masyarakat yang menolak vaksinasi Covid-19

Selanjutnya bentuk respons netizen terhadap netizen lain yang melakukan penolaka. Respons ini sebenarnya adalah aksi satire yang dilakukan masyarakat yang mendukung adanya vaksinasi agar pandemi Covid-19 segera berakhir. Berikut postingannya.

Gambar 6. Capture postingan respons netizen terhadap netizen lain yang melakukan penolakan vaksinasi Covid-19
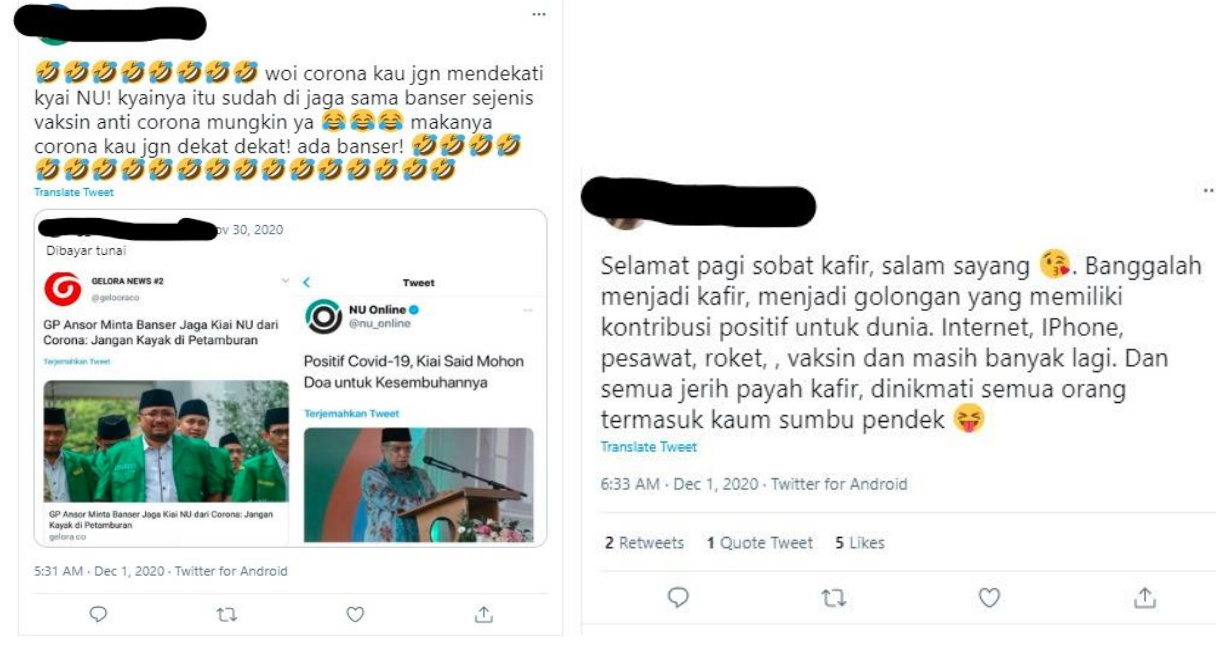

Sumber: Data pribadi

7. Postingan sebagai respons terhadap peristiwa lain selama pandemi Covid-19

Terakhir adalah postingan netizen sebagai respons terhadap peristiwa yang dianggap melanggar protokol kesehatan selama pandemi Covid-19 dan menganggap Indonesia perlu segera melakukan vaksinasi Covid-19. Berikut postingannya.

Gambar 7. Capture postingan netizen sebagai respons terhadap peristiwa yang melanggar protokol kesehatan Covid-19
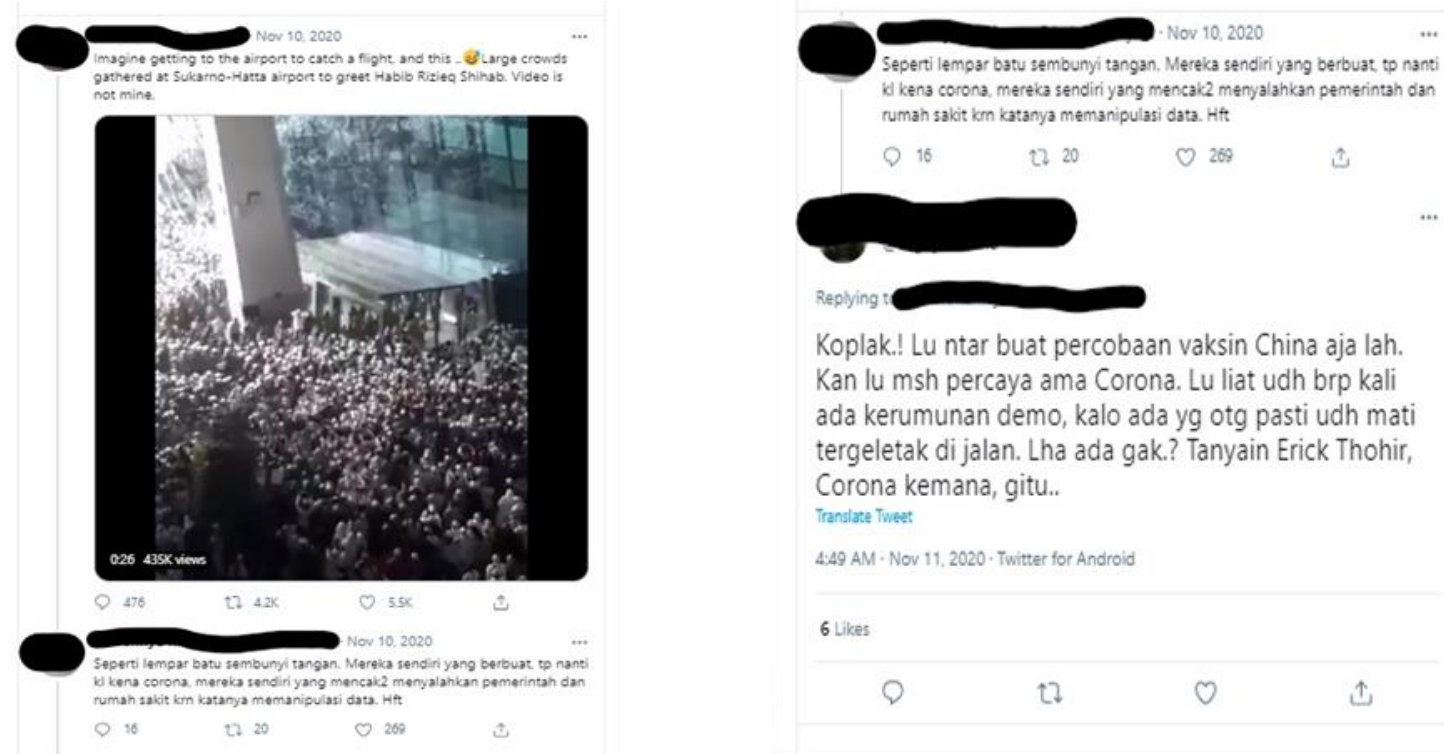

Koplak.! Lu ntar buat percobaan vaksin China aja lah. Kan lu msh percaya ama Corona. Lu liat udh brp kali ada kerumunan demo, kalo ada yg otg pasti udh mati tergeletak di jalan. Lha ada gak.? Tanyain Erick Thohir, Corona kemana, gitu.. Transiate Tweet

4:49 AM - Nov 11, 2020 - Twitter for Android

6 Likes

64

Sumber: Data pribadi

Tujuh bentuk respons netizen ini merupakan perilaku sosial masyarakat yang terbentuk di Twitter selama pandemi Covid-19. Anggap saja saya dan pembaca tidak mengetahui maksud dan 
penyebab di balik perilaku tersebut, postingan yang saya tunjukkan tersebut tidak lebih hanya teknik respons manusia terhadap isu. Dengan kata lain, perilaku tersebut bersifat relatif untuk menanggapi isu yang ada saat berinteraksi (Nisrima et al., 2016), misalnya dalam postingan tersebut ada netizen yang marah, senang, bercanda, sedih, dan sebagainya.

\section{Postingan dan Respons sebagai Proses Intersubjectivity-telecopresence}

Sebelumnya, telah dijelaskan bagaimana postingan dan respons terhadap postingan menjadi bagian dari perilaku sosial. Persoalannya adalah perilaku sosial yang di bahas Prof. Wirawan (2012) tidak melihat penyebab dan motivasi atas perilaku tersebut. Penelitian ini ingin menambah informasi mengenai paradigma perilaku sosial dan mengkaitkan dengan paradigma lain yang dapat menjelaskan interaksi lebih dalam. Interaksi selama masa pandemi Covid-19, di mana kebijakan PSBB (Pembatasan Sosial Berskala Besar) menyebabkan masyarakat tidak dapat keluar rumah, berkumpul, dan melakukan interaksi secara fisik memanfaatkan dunia maya untuk berinteraksi dengan sesamanya (Sebayang, 2020).

Twitter merupakan media sosial yang banyak digunakan oleh netizen untuk berargumen, berkomentar, berdiskusi, dan memberikan informasi ke sesama penggunanya (Sinuhaji, 2020) dengan tujuan agar saling bertukar informasi atas suatu peristiwa yang sedang terjadi. Pandemi Covid-19 ini merupakan isu penting yang selalu dibahas, netizen secara sadar membagikan informasi mengenainya dan secara sadar menerima informasi tersebut sebagai bentuk pengetahuan. Perilaku sadar ini bukan hanya perilaku empiris tanpa ada penyebabnya, melainkan perilaku sadar bahwa manusia sebagai pribadi membutuhkan informasi untuk menghadapi peristiwa baru yang belum pernah dialami sebelumnya dengan melihat atau mengamati pengalaman dan pengetahuan orang lain.

Gambar 8. Capture diskusi netizen mengenai gejala Covid-19
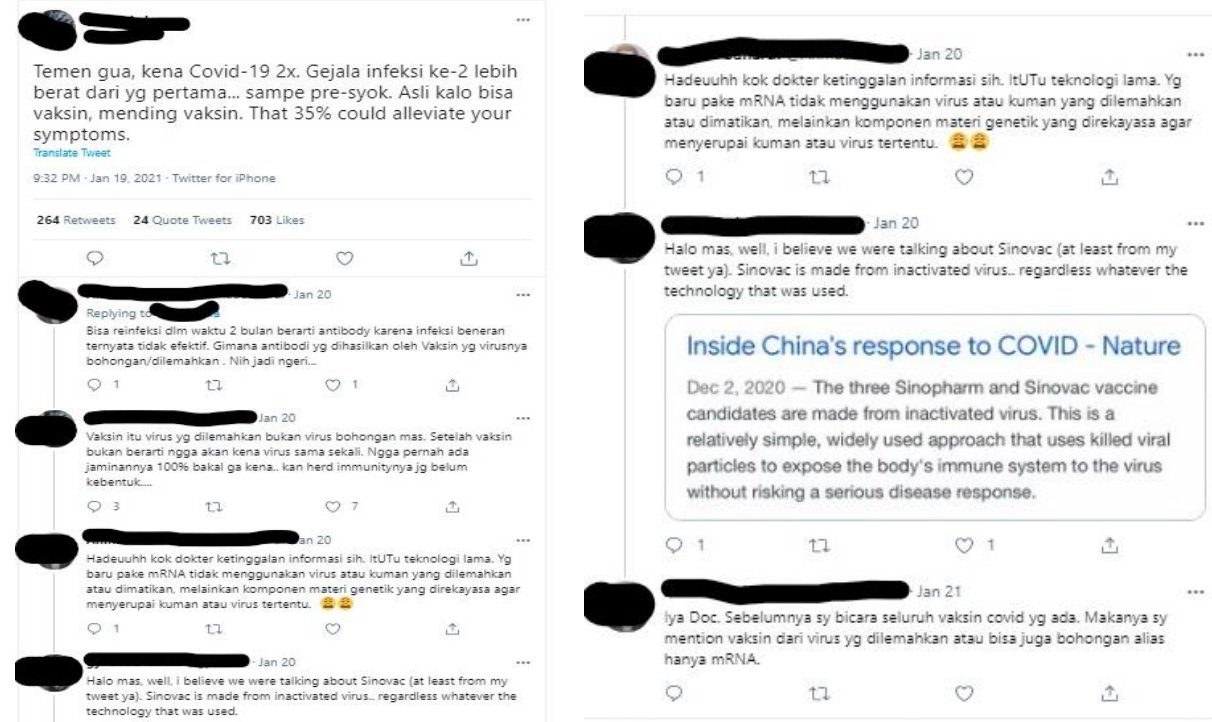

Sumber: Data pribadi

Interaksi yang terjadi seperti gambar 8 menunjukkan bahwa satu netizen dan lainnya melakukan diskusi panjang untuk bertukar informasi mengenai gejala yang ditimbulkan ketika manusia terdampak virus ini. Pengetahuan yang secara sadar didapatkan dalam diskusi tersebut dapat digunakan untuk dirinya dalam bertindak ketika ia atau orang disekitarnya terdampak virus Covid19. Tidak dapat saya pastikan apakah diskusi yang saya sematkan tersebut adalah dua orang yang saling mengenal, namun penelitian ini tidak berfokus terhadap hal tersebut (meskipun "subjek" menjadi penting untuk mengukur seberapa besar informasi yang berikan dapat memengaruhi orang 
lain dan sebaliknya). Gambar 8 tersebut menunjukkan bahwa interaksi yang terjadi bukan hanya sekadar perilaku sosial manusia tanpa penyebab, tetapi dilakukan dengan tujuan tertentu, dalam kasus ini adalah informasi mengenai gejala virus Covid-19.

Diskusi di sosial media selama pandemi Covid-19 berlangsung berulang-ulang sampai isu vaksinasi Covid-19. Perilaku diskusi yang dilakukan hampir sama dengan perilaku yang telah ada sebelumnya (PSBB dan new normal )selama pandemi Covid-19.

Gambar 9. Capture diskusi netizen mengenai vaksin Covid-19
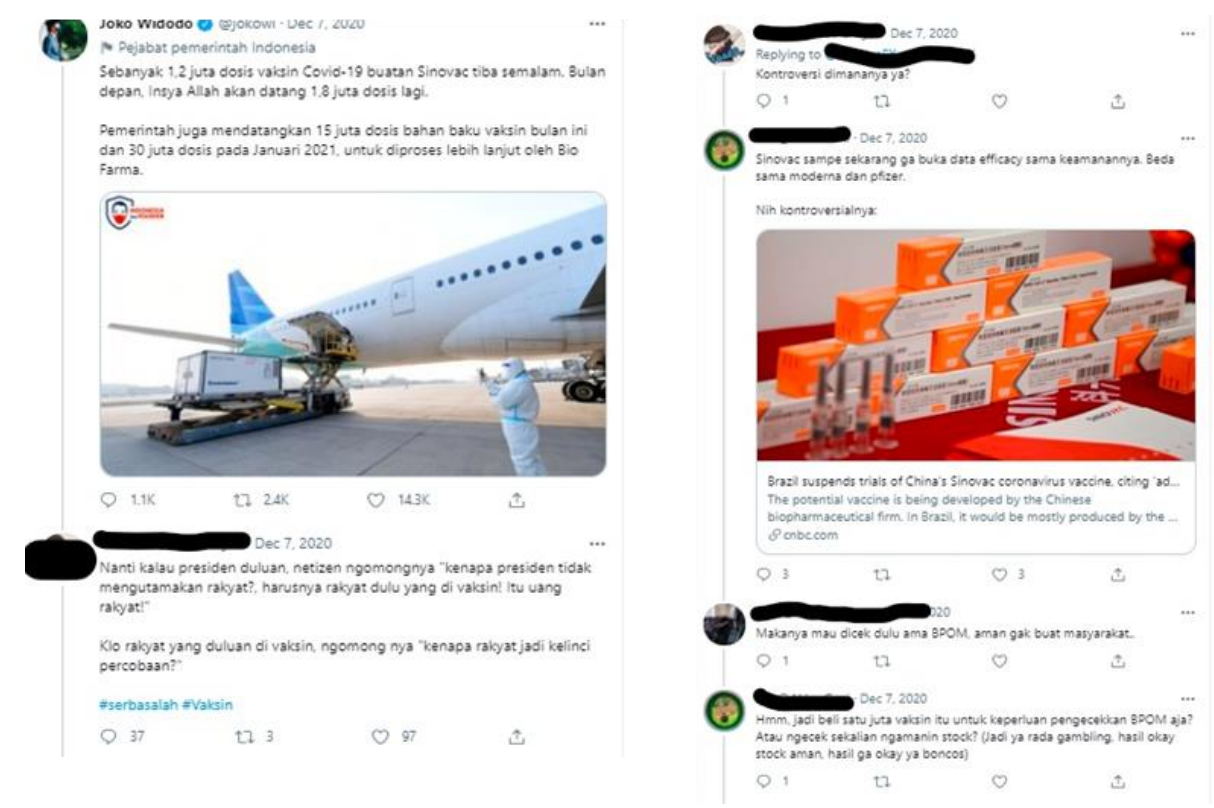

Sumber: Data pribadi

Gambar 9 menunjukkan bahwa kembali terjadi polarisasi di masyarakat sebagai akibat dari respons akan dilakukannya vaksinasi Covid-19 di Indonesia. Perilaku diskusi (interaksi) ini merupakan proses yang disebut oleh Schutz yaitu intersubjectivity, bahwa interaksi yang terjadi antar manusia bertujuan untuk mendapatkan pengetahuan dari pengalaman yang dimiliki oleh manusia lainnya. Sedangkan Zhao menyebutnya sebagai telecopresence di mana intersubjectivity tersebut berlaku juga dalam dunia maya yaitu media sosial (Aulia, 2018). Jadi perilaku sosial (interaksi) di Twitter yang dilakukan oleh netizen selama masa pandemi memiliki penyebab atau motivasi dibelakangnya. Netizen memerlukan informasi dari interaksi tersebut mengenai Covid-19 guna dimanfaatkan dalam merespons peristiwa yang terjadi selama pandemi.

\section{Self-evidence: Pembuktian Diri dalam Merespons Peristiwa Selama Masa Pandemi Covid-19}

Saya telah menjelaskan bagaimana perilaku sosial dan intersubjectivity-telecopresence berlaku dalam interaksi dan respons terhadap interaksi tersebut bekerja, bukan sebagai konsep tunggal melainkan saling melengkapi untuk memahami bagaimana interaksi dalam media sosial. Merupakan sikap yang alami bagi manusia ketika ia membentuk hubungan dengan individu lain untuk mendapatkan pengetahuan dan pengalaman yang berfungsi sebagai referensi bertindak dalam peristiwa tertentu (Aulia, 2018). Meskipun yang harus diperhatikan bahwa manusia akan berkembang atau berubah berdasarkan peristiwa yang dijumpainya, maksudnya manusia akan terus-menerus membentuk hubungan (interaksi) untuk mendapatkan pengetahuan guna merespons peristiwa yang sedang terjadi. 
Gambar 10. Capture postingan netizen mengenai vaksin dan vaksinasi Covid-19
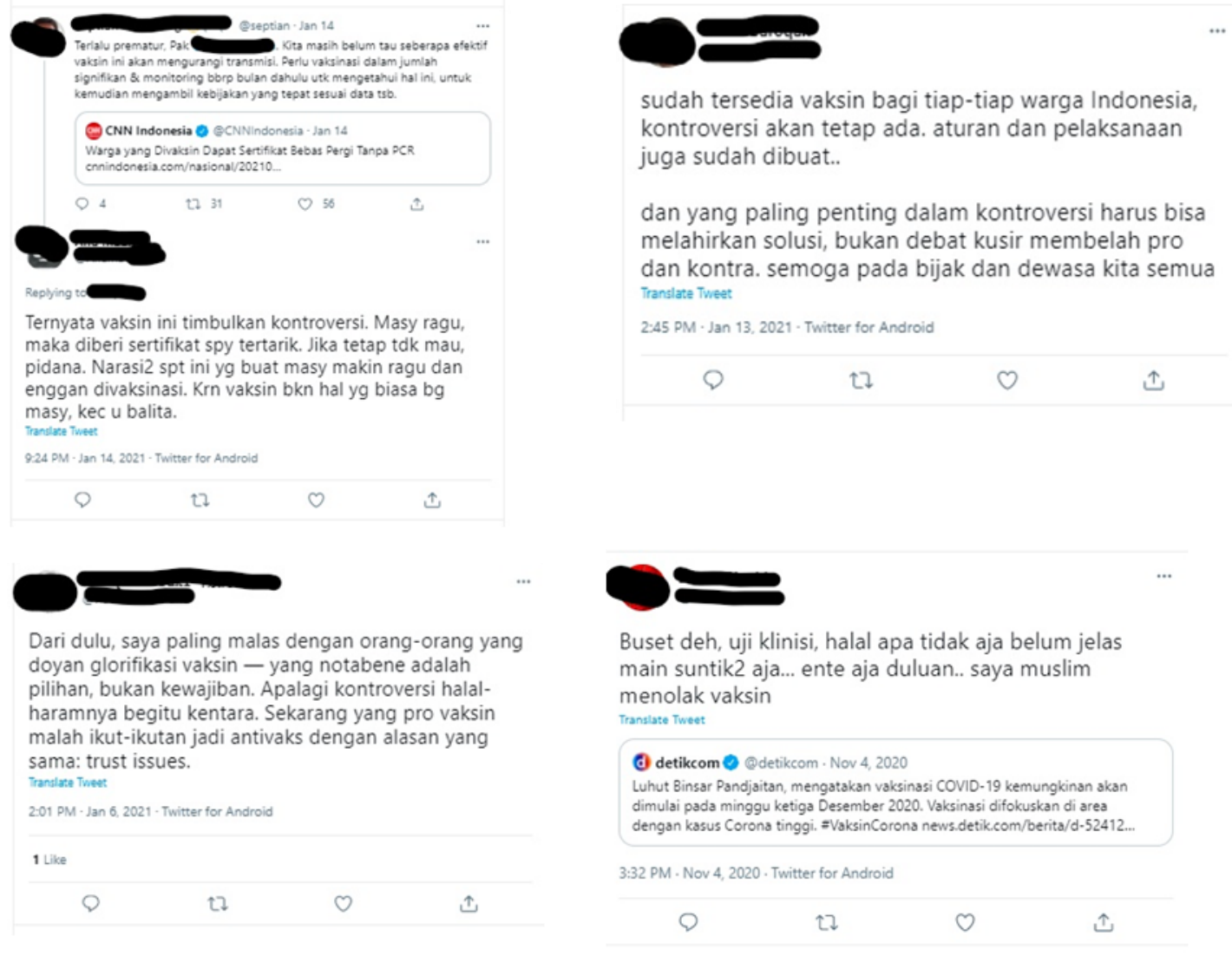

Sumber: Data Pribadi

Pengalaman dan pengetahuan yang ditransfer dari interaksi yang dilakukan dapat berguna untuk menemukan jawaban (kebenaran) yang secara sadar dipahami oleh manusia. Pemahaman secara sadar ini kemudian disebut oleh Schutz sebagai "self-evidence" atau bukti diri seperti pada gambar.10 tersebut (Aulia, 2018), bahwa interaksi memiliki penyebab dan dampak yang dirasakan oleh manusia meskipun peristiwa atau situasi yang dialami dapat berubah-ubah sepanjang waktu. Awal tulisan ini saya memberikan contoh bahwa saat pandemi berlangsung, masyarakat dihadapkan dalam situasi polarisasi, di mana masyarakat terbagi menjadi "mendukung" atau "tidak mendukung". Secara alami sejak awal pendemi, masyarakat telah banyak melakukan diskusi untuk mendapatkan referensi guna menghadapi pandemi, proses interaksi tersebut terjadi berulang-ulang sampai polarisasi juga terjadi isu vaksinasi Covid-19. Proses berulang inilah yang disebut sebagai "self-evidence", di mana manusia mengonfirmasi pengetahuannya atau menambahnya. Jadi ketika diskusi mengenai vaksinasi berlangsung netizen telah memiliki pengetahuan mengenai Covid-19 yang telah didiskusikan sebelumnya sehingga postingan atau respons atas postingan yang terjadi bisa dikonfirmasi kebenarannya dan diamati lebih baik dengan referensi yang telah dimiliki sebelumnya.

\section{Simpulan}

Pandemi Covid-19 menjadikan masyarakat berinteraksi lebih aktif di media sosial, khususnya Twitter. Perilaku sosial yang ditunjukkan merupakan awal sikap alami manusia yang dilakukan secara sadar atas respons dari peristiwa yang sedang terjadi. Penelitian ini merujuk pada bagaimana perilaku sosial tidak dipandang sebagai paradigma tunggal, tetapi digabungkan dengan paradigma lain untuk melihat interaksi di masyarakat. Subjectivity-telecopresence mampu menambahkan penjelasan perilaku manusia yang rumit di masyarakat dalam penelitian ini adalah masa pandemi Covid-19. 
Interaksi sebagai bentuk transfer pengetahuan terjadi berulang-ulang sebagai referensi dalam bertindak saat terjadi peristiwa tertentu. Interaksi yang berulang-ulang ini membentuk self-evidence manusia, di mana dapat berguna untuk mendapatkan kebenaran dan pengamatan lebih baik dalam merespons peristiwa yang sedang terjadi.

\section{Daftar Pustaka}

Administrator. (2020). Mengenal Konsep New normal. Diakses dari https://indonesia.go.id/kategori/kuliner/1859/mengenal-konsep-new-normal

Advetorial, CNN Indonesia. (2020, Juni 17). Menyelamatkan Ekonomi Indonesia Melalui Penerapan New normal. CNN Indonesia. Diakses dari https://www.cnnindonesia.com/ekonomi/20200616191535-297-514013/menyelamatkanekonomi-indonesia-melalui-penerapan-new-normal

Franedya, Roy. (2020, Desember 07). Kabar Terbaru Perlombaan Penemuan vaksin Corona versi WHO. CNBC Indonesia. Diakses dari https://www.cnbcindonesia.com/tech/20201207135651-37-207365/kabar-terbaruperlombaan-penemuan-vaksin-corona-versi-who

Ihsanuddin. (2020, Maret 03). Fakta Lengkap Kasus Pertama Virus Corona di Indonesia. Kompas.com. Diakses dari https://nasional.kompas.com/read/2020/03/03/06314981/faktalengkap-kasus-pertama-virus-corona-di-indonesia?page $=$ all

Jaya, Indra B. (2020). Relasi Masjid dan Pasar: Kajian Sosiologi Hukum Terhadap Kebijakan Penerapan Pembatasan Sosial Berskala Besar Saat Pandemi Covid-19. Fastabiq: Jurnal Studi Islam, 1(2), 120-131. ISSN: 2723-0228

Kementerian Kesehatan RI. (2014). Buku Ajar Imunisasi. Jakarta, Indonesia: Author.

Manurung, A. (2020, April 24). Tren Kriminalitas Meningkat Saat PSBB Berjalan. Tempo.co. Diakses dari https://fokus.tempo.co/read/1335238/tren-kriminalitas-meningkat-saat-psbbberjalan/full\&view=ok

Mashabi, S. (2020, Septermber 03). 6 Bulan Pandemi Covid-19: Catatan tentang PSBB dan Penerapan Protokol Kesehatan... Kompas.com. Diakses dari https://nasional.kompas.com/read/2020/09/03/09002161/6-bulan-pandemi-covid-19-catatantentang-psbb-dan-penerapan-protokol?page=all

Nicolas, Djone G. (2021). Analisis Kontroversi Vaksin Covid-19, Microchip 666 dan Antrikris Di Tengah Gereja Di Indonesia Berdasarkan Wahyu 13:16-18. Syntax Literate: Jurnal Ilmiah Indonesia, 6(2), 664-671. e-ISSN: 2548-1398.

Nisrima, S., Yunus., M., \& Hayati, E. (2016). Pembinaan Perilaku Sosial remaja Penghuni Yayasan Islam Media Kasih Kota Banda Aceh. Jurnal Ilmiah Mahasiswa Pendidikan Kewarganegaraan Unsyiah, 1(1), 192-204.

Rosana, Francisca C. (2020, Desember 13). 6 Kontroversi Vaksin: Penolakan Masyarakat hingga Jokowi Tak Mau Disuntik Duluan. Tempo.co. Diakses dari https://bisnis.tempo.co/read/1413983/6-kontroversi-vaksin-penolakan-masyarakat-hinggajokowi-tak-mau-disuntik-duluan?page_num=3

Sebayang, Reiha. (2020, Juli 24). Di Tengah Pandemi, Penggunaan Teknologi Meningkat Pesat. CNBC Indonesia. Diakses dari https://www.cnbcindonesia.com/tech/20200723190647-37175009/di-tengah-pandemi-penggunaan-teknologi-meningkat-pesat

Silalahi, P. (2020). Menuju Normal Baru, Bappenas Rumuskan Protokol Masyarakat Produktif dan Aman Covid-19. Diakses dari https://covid19.go.id/p/berita/menuju-normal-baru-bappenasrumuskan-protokol-masyarakat-produktif-dan-aman-covid-19

Sinuhaji, Julkifli. (2020, Juli 25). Dunia Terisolasi Pandemi Covid-19, Pengguna Twitter Meningkat. PikiranRakyatcom. Diakses dari https://www.pikiran-rakyat.com/teknologi/pr01634954/dunia-terisolasi-pandemi-covid-19-pengguna-Twitter-meningkat 
Sukmani, Khoirun N A. (2018). Lifeworld Fotografer Human Interest: Berkarya di Media Sosial Instagram. (Unpublished master's thesis). Univeristy of Indonesia, Depok, Jakarta.

Tambunan, Liza. (2020, Juli 13). Virus corona di Indonesia: Kapan puncak pandemi akan terjadi setelah penerapan 'new norma'? BBC News Indonesia. Diakses dari https://www.bbc.com/indonesia/indonesia-53380880

Twitter. (n.d.) Retweet FAQs. Diakses dari https://help.Twitter.com/en/using-Twitter/retweet-faqs

Webmaster. (2020). Penerapan Jaga Jarak Fisik / Physical Distancing Dalam Pencegahan Covid-19/ Corona Virus. Diakses dari https://dishub.kukarkab.go.id/pages/penerapan-jaga-jarak-fisikphysical-distancing-dalam-pencegahan-covid-19-corona-virus

Wibowo, A. (2020). Kemenkes: PSBB Batasi Kegiatan Tertentu di Wilayah Terduga Covid-19. Diakses dari https://covid19.go.id/p/berita/kemenkes-psbb-batasi-kegiatan-tertentu-diwilayah-terduga-covid-19

Wirawan., I.B. (2012). Teori-Teori Sosial Dalam Tiga Paradigma (Fakta Sosial, Definisi Sosial, dan Perilaku Sosial. Jakarta, Indonesia: Prenamedia Group.

Wirawan. Miranti K. (2020, Desember 20). Kekhawatiran Umat Islam Indonesia akan Status Halal Vaksin Covid-19 Disorot Media Amerika. Kompas.com. Diakses dari https://www.kompas.com/global/read/2020/12/20/173249070/kekhawatiran-umat-islamindonesia-akan-status-halal-vaksin-covid-19?page=all 